\title{
Dynamin 3: a new candidate tumor suppressor gene in hepatocellular carcinoma detected by triple combination array analysis
}

\author{
Yoshikuni Inokawa' \\ Shuji Nomoto' \\ Mitsuhiro Hishida' \\ Masamichi Hayashi' \\ Mitsuro Kanda' \\ Yoko Nishikawa' \\ Shin Takeda ${ }^{2}$ \\ Michitaka Fujiwara' \\ Masahiko Koike' \\ Hiroyuki Sugimoto' \\ Tsutomu Fujii' \\ Goro Nakayama' \\ Suguru Yamada' \\ Chie Tanaka' \\ Daisuke Kobayashi' \\ Yasuhiro Kodera' \\ 'Gastroenterological Surgery, \\ Nagoya University Graduate School \\ of Medicine, Nagoya Japan; \\ ${ }^{2}$ Department of Surgery, Nagoya \\ Medical Center, Nagoya, Japan
}

This article was published in the following Dove Press journal:

OncoTargets and Therapy

8 October 2013

Number of times this article has been viewed

Background: To identify genes associated with hepatocellular carcinoma (HCC) pathogenesis, we developed a triple combination array strategy comprising methylation, gene expression, and single nucleotide polymorphism (SNP) array analysis.

Methods: Surgical specimens obtained from a 68-year-old female HCC patient were analyzed by triple combination array, and identified Dynamin 3 (DNM3) as a candidate tumor suppressor gene in HCC. Subsequently, samples from 48 HCC patients were evaluated for DNM3 methylation and expression status using methylation specific polymerase chain reaction (PCR; MSP) and semi-quantitative reverse transcriptase (RT)-PCR, respectively. The relationship between clinicopathological factors and DNM3 methylation status was also investigated.

Results: $D N M 3$ was shown to be hypermethylated (methylation value 0.879 , range $0-1.0$ ) in cancer tissue compared with adjacent normal tissue $(0.213)$ by methylation array in the 68-year-old female patient. Expression arrays revealed decreased expression of DNM3 in cancerous tissue. SNP arrays revealed that the copy number of chromosome 1q24.3, in which $D N M 3$ resides, was normal. MSP revealed hypermethylation of the DNM3 promoter region in 33 of 48 tumor samples. A trend toward decreased DNM3 expression was observed in patients with $D N M 3$ promoter methylation $(P=0.189)$. Furthermore, patients with reduced expression of DNM3 in tumor tissues exhibited worse prognosis with decreased disease specific survival compared to patients without decreased expression $(P=0.014)$.

Conclusion: The present study indicates that a triple combination array strategy is an effective method to detect novel genes related to HCC. We propose that DNM3 is a tumor suppressor gene in HCC.

Keywords: $D N M 3$, hepatocellular carcinoma, methylation, triple combination array

\section{Introduction}

Hepatocellular carcinoma (HCC) is currently the sixth most prevalent neoplasm and the third most frequent cause of cancer death worldwide, ${ }^{1}$ and its overall incidence is steadily rising. Although several therapeutic options for the treatment of HCC currently exist, ${ }^{2-5}$ the prognosis of patients with advanced HCC remains poor. ${ }^{6,7}$ Therefore, further research to clarify the mechanisms underlying hepatocarcinogenesis is urgently required. ${ }^{8}$

We recently developed a double combination array analysis consisting of gene expression and single nucleotide polymorphism (SNP) array analysis, and reported a number of tumor suppressor genes in HCC. ${ }^{9-14}$ In these studies, we hypothesized that deoxyribonucleic acid (DNA) methylation of the promoter region of these genes led to downregulation of gene expression, causing HCC progression. In addition to

\footnotetext{
Correspondence: Shuji Nomoto

Gastroenterological Surgery, Nagoya University Graduate School of Medicine, 65 Tsurumai-cho, Showa-ku, Nagoya 466-8550, Japan Tel +8I 527442249

Fax +8I 527442255

Email snomoto@med.nagoya-u.ac.jp
} 
this double combination array analysis, we also performed methylation array analysis of the same specimens, thus allowing a more conclusive association between gene expression and DNA methylation. This triple combination array analysis represents an efficient procedure for the detection of tumor suppressor genes of HCC. ${ }^{15,16}$

Dynamin 3 (DNM3) is a candidate tumor suppressor gene detected by this triple combination array analysis. This gene encodes a member of the dynamin family, which possess mechanochemical properties used to tabulate and sever membranes. ${ }^{17}$ However, to date, there are few reports describing the relationship between DNM3 and any malignant disease. ${ }^{18,19}$ Furthermore, no previous studies have investigated the role of DNM3 in HCC. In this study, we aimed to evaluate the expression and methylation status of DNM3 in HCC.

\section{Materials and methods}

\section{Sample collection and DNA preparation}

Nine HCC cell lines (HepG2, Hep3B, HLE, HLF, HuH1, $\mathrm{HuH} 2, \mathrm{HuH} 7, \mathrm{PLC} / \mathrm{PRF} / 5$ and SK-Hep1) were obtained from the American Type Culture Collection (ATCC, Manassas, VA, USA). All cell lines were cultured in Roswell Park Memorial Institute (RPMI)-1640 medium supplemented with 10\% fetal bovine serum and incubated in $5 \% \mathrm{CO}_{2}$ at $37^{\circ} \mathrm{C}$.

A 68-year-old woman with chronic hepatitis $\mathrm{C}$ was diagnosed with HCC in the right lobe and biochemical examination showed that des-gamma-carboxy (DCP) prothrombin level was as high as $7029 \mathrm{mAU} / \mathrm{mL}$ whereas alpha-fetoprotein (AFP) level was $9 \mathrm{ng} / \mathrm{mL}$. She underwent partial liver resection. Specimens of her tumor and adjacent non-tumorous tissues were excised. The tumor was pathologically confirmed as moderately differentiated HCC and the surrounding parenchymal tissue showed liver cirrhosis.

HCC tissue (HT) and normal tissue (NT) samples were obtained from 48 patients (43 males, five females, aged between 39-77 years, mean \pm standard deviation [SD], $62.4 \pm 7.9$ years) who underwent liver resection at Nagoya University Hospital, Nagoya, Japan between 1994 and 2001. Thirty-eight patients had hepatitis $\mathrm{C}$ and seven had hepatitis B. The median duration of follow-up was 80.7 months (range 15.2-213.1 months). All tissues were reviewed pathologically to confirm the diagnosis of HCC. Written informed consent, as required by the institutional review board, was obtained from all patients. The tissue samples were immediately frozen in liquid nitrogen and stored at $-80^{\circ} \mathrm{C}$ until required. Genomic DNA was obtained from tissue samples by proteinase $\mathrm{K}$ digestion, followed by phenol/chloroform extraction.

\section{Ribonucleic acid isolation, microarray, and gene chip affymetrix procedures}

Gene expression and SNP arrays were performed as previously described, ${ }^{9-14}$ using total ribonucleic acid (RNA) and DNA extracted from tissue samples taken from the 68-year-old female patient described above. Total RNA and DNA were extracted from an area consisting of $>80 \%$ cancerous cells. RNA was isolated from each of the frozen samples with the RNeasy mini kit (Qiagen, Chatsworth, CA, USA) according to the manufacturer's protocol. Total RNA was processed for expression array analysis by Affymetrix HGU133A and HGU133B Gene Chips (Affymetrix, Santa Clara, CA, USA). Genomic DNA was used for SNP-Chip array analysis by Affymetrix GeneChip Mapping $500 \mathrm{~K}$ arrays (Affymetrix).

\section{Methylation array platform}

Methylation arrays were performed using DNA extracted from tissue samples taken from the 68-year-old female patient described above. Bisulfite-converted DNA (500 ng to $1 \mu \mathrm{g}$ ) was used for DNA methylation analysis using Ilumina Infinium Human Methylation 27 BeadChip arrays (Illumina, San Diego, CA, USA). ${ }^{20}$ Of the $\sim 28$ million $\mathrm{CpG}$ sites identified throughout the haploid human genome, Illumina initially designed Infinium methylation probes for 27,578 $\mathrm{CpG}$ sites located in promoter regions (up to $1 \mathrm{~kb}$ upstream or $500 \mathrm{bp}$ downstream of the transcription start sites). Of these, $27,324 \mathrm{CpG}$ sites relate to 14,475 consensus coding sequences, including approximately 1,000 cancerassociated genes, and $254 \mathrm{CpG}$ sites relate to approximately 100 microRNA genes. The probes were preferentially selected to occur within $\mathrm{CpG}$ islands using the National Center for Biotechnology Information (NCBI) "relaxed" definition of a $\mathrm{CpG}$ island: $\mathrm{CpG}$ islands identified bioinformatically with a $\mathrm{CpG}$ content of $>50 \%$ and an observed/ expected ratio of $>0.6 .{ }^{21}$

Bisulfite-converted DNA was whole-genome amplified, enzymatically fragmented, and hybridized to arrays. During hybridization, the bisulfite-converted DNA anneals to methylation-specific probes on the chip. Each $\mathrm{CpG}$ locus is represented by two bead types, one of which is specific to the methylated state and the other specific to the unmethylated state, which is directly related to the underlying sequence change catalyzed during bisulfite conversion. Therefore, for each $\mathrm{CpG}$ site, a possible $\mathrm{C} / \mathrm{T}$ variant can be assayed through the single-base extension step, which is possible because of the ability to hybridize to either the "protected" methylated cytosine or the converted (unmethylated) thymine. 
After hybridization, a single-base extension step was performed using a multi-layer staining process, as described below. The BeadChip was then scanned on the Illumina iScan and the resulting "idat" files were analyzed using BeadStudio software (Illumina, San Diego, CA, USA). The output of the BeadStudio analysis is a $\beta$-value for each $\mathrm{CpG}$ site. This is a continuous value between 0 and 1 , where $0=0 \%$ methylation and $1=100 \%$ methylation at a given $\mathrm{CpG}$ site. Therefore, this assay enables quantitative analysis of methylation at individual $\mathrm{CpG}$ sites.

\section{Reverse transcription-polymerase chain reaction}

DNM3 messenger (m)RNA expression was analyzed by semiquantitative reverse transcription-polymerase chain reaction (RT-PCR) and real-time RT-PCR. Total RNA $(10 \mu \mathrm{g})$ isolated from nine HCC cell lines, primary HTs and NTs were used to generate complementary DNA (cDNA). The resulting cDNAs were then amplified by PCR using primers for $D N M 3$ (sense, 5'-ACC CCA CAC CTG CAG AAG GT-3' in exon 6); antisense 5'-TGG AGA GCA ACT GTC CCT GTA-3' in exon 7), which amplified a $100 \mathrm{bp}$ product. $\mathrm{PCR}$ was performed using the following parameters: initial denaturation at $94^{\circ} \mathrm{C}$ for 5 minutes followed by 35 cycles of $94^{\circ} \mathrm{C}$ for 10 seconds, $60^{\circ} \mathrm{C}$ for 8 seconds and $72^{\circ} \mathrm{C}$ for 4 seconds. RT-PCR of $\beta$-actin was performed to confirm equal amounts of cDNA template in each amplification. Each PCR product was loaded directly onto 3\% agarose gels, stained with ethidium bromide and visualized under ultraviolet (UV) illumination.

\section{Real-time quantitative RT-PCR analysis}

PCR was performed using SYBR Green PCR Core Reagents (Perkin-Elmer Applied Biosystems, Foster City, CA, USA) under the following conditions: 1 cycle at $95^{\circ} \mathrm{C}$ for 10 seconds, followed by 48 cycles at $95^{\circ} \mathrm{C}$ for 10 seconds and at $60^{\circ} \mathrm{C}$ for 30 seconds. SYBR Green emission was detected in real-time with an ABI prism 7000 Sequence Detector (Perkin-Elmer Applied Biosystems). The primers used for PCR were the same as those described above for RT-PCR. Quantitative RTPCR was performed at least three times, including negative controls without template. The expression of DNM3 was normalized to glyceraldehyde 3-phosphate dehydrogenase (GAPDH) expression in each sample.

\section{Methylation-specific PCR}

DNA from HCC cell lines, HTs and NTs were subject to bisulfite treatment. Briefly, $2 \mu \mathrm{g}$ of DNA was denatured by $\mathrm{NaOH}$ and modified by sodium bisulfite. DNA samples were then purified using the Wizard purification resin (Promega Corporation, Madison, WI, USA), treated with $\mathrm{NaOH}$, precipitated with ethanol and resuspended in water. Primer pairs were used to detect methylation (sense, $5^{\prime}$-GAG GTC GTG GTA TTT GGT CG-3'; antisense, 5'-AAC GCG CCT ACG CGA ACG AA-3'; 149-bp product) and nonmethylation (sense, 5'-GGG GTG TTG TGG AGA TAG GT-3'; antisense, 5'-CCA CCA ACC CAC CAC TTA AC-3'; 90-bp product) of the DNM3 promoter region near exon 1. Methylation-specific PCR (MSP) amplification was performed as follows: denaturation at $94^{\circ} \mathrm{C}$ for 5 minutes followed by 44 cycles at $94^{\circ} \mathrm{C}$ for 15 seconds, $60^{\circ} \mathrm{C}$ for 10 seconds and $72^{\circ} \mathrm{C}$ for 9 seconds. Unmethylated-Specific PCR (UNMSP) amplification was performed as follows: denaturation at $94^{\circ} \mathrm{C}$ for 5 minutes followed by 36 cycles at $94^{\circ} \mathrm{C}$ for 15 seconds, $60^{\circ} \mathrm{C}$ for 10 seconds and $72^{\circ} \mathrm{C}$ for 8 seconds. PCR products were loaded directly onto $3 \%$ agarose gels, stained with ethidium bromide and visualized under UV illumination.

\section{Sequence analysis}

Bisulfite-treated genomic DNA obtained from HCC cell lines was sequenced and PCR was performed in all cases. Semi-nested PCR was performed to gain adequate products for TA cloning. PCR amplification was performed as follows: denaturation at $94^{\circ} \mathrm{C}$ for 3 minutes followed by 37 cycles of $94^{\circ} \mathrm{C}$ for 15 seconds, $54^{\circ} \mathrm{C}$ for 15 seconds, and $72^{\circ} \mathrm{C}$ for 20 seconds with primer pairs (sense 5'-TTG GGT TTT GGT TTG GTA GT-3'; antisense, 5' - TCA ACC AAC CAA ATC CTA AC-3'; 342-bp product). $\mathrm{PCR}$ products were used as templates for subsequent PCR using the same antisense primer and a different sense primer (sense, 5'-GGT TTT TGA GTT TTG GTT ATA G-3'; 253-bp product). The $\mathrm{PCR}$ products were subcloned into a TA cloning vector (Invitrogen, Carlsbad, CA, USA). Six clones were selected from two HCC cell lines (HuH2 and PLC/PRF/5). Each DNA clone was mixed with $3 \mu \mathrm{L}$ of M13 specific primer and $4 \mu \mathrm{L}$ of Cycle Sequence Mix (ABI PRISM Terminator v1. 1 Cycle Sequencing Kit; Applied Biosystems, Foster City, CA, USA). Samples were then subjected to the following cycling conditions: $95^{\circ} \mathrm{C}$ for 30 seconds followed by 25 cycles of $96^{\circ} \mathrm{C}$ for 10 seconds, $50^{\circ} \mathrm{C}$ for 5 seconds and $60^{\circ} \mathrm{C}$ for 4 minutes, and purified by ethanol precipitation. Sequence analysis was performed using an Applied Biosystems ABI310 and sequence electropherograms were generated using ABI Sequence Analysis software version 3.0.

\section{5-aza-2'-deoxycytidine treatment}

HCC cell lines were treated with $1 \mu \mathrm{M} 5$-aza-2'-deoxycytidine (5-aza-dC) (Sigma-Aldrich, St Louis, MO, USA) to inhibit 
DNA methylation. Cells $\left(1.5 \times 10^{6}\right)$ were cultured for 6 days with medium changes on days 1,3 , and 5 . On day 6 , cells were harvested, RNA was extracted and RT-PCR was performed as described above.

\section{Statistical analysis}

Continuous variables are expressed as medians (range) and comparisons were made using the Mann-Whitney U test. Categorical variables were compared using $\chi^{2}$ tests or Fisher's exact tests, where appropriate. Disease specific survival rates were analyzed by Kaplan-Meier and log-rank tests. All statistical analyses were performed using JMP software version 9.0.2 (SAS International Inc., Cary, NC, USA). The level of statistical significance was set at $P<0.05$.

\section{Results}

\section{Results of expression, SNP, and methylation-arrays}

To identify novel tumor-related genes in $\mathrm{HCC}$, we first searched for genes with decreased expression in HCC samples compared with corresponding normal tissue. According to the expression array results, DNM3 was strongly downregulated in HCC tissue ( $\log 2$ ratio -1.0, 2-fold decrease in expression; Table 1). Decreased expression of DNM3 mRNA was subsequently confirmed by semi-quantitative RT-PCR in tumor tissue from the same patient (Figure 1A).

SNP array analysis of DNA from the same patient revealed deletions in chromosomes $3 \mathrm{q}, 8 \mathrm{p}, 11 \mathrm{q}, 12 \mathrm{p}, 12 \mathrm{q}$, $16 \mathrm{p}, 17 \mathrm{p}, 19 \mathrm{p}$, and $\mathrm{X}$, and chromosomal gains in 1q, 3q, 11q, $12 \mathrm{p}$, and $12 \mathrm{q}$. Although we observed amplifications affecting chromosome 1, which contain the DNM3 gene, no deletions were observed (Figure 1B). A detailed analysis of the SNP array at the DNM3 gene locus (1q24.3) identified 61 SNPs. Of these 61 SNPs, three exhibited a heterozygous AB allele in both the non-cancerous and cancerous samples (Table 2). These results suggest that the DNM3 gene locus retained biallelically, and the expression of DNM3 was diminished without chromosomal deletion.

Table I Expression array analysis of surgical samples from a 68-year-old female patient with HCC

\begin{tabular}{llllll}
\hline $\begin{array}{l}\text { Probe } \\
\text { set ID }\end{array}$ & $\begin{array}{l}\text { Gene } \\
\text { symbol }\end{array}$ & $\begin{array}{l}\text { Log2 } \\
\text { ratio }\end{array}$ & Sample & Signal & Detection \\
\hline 209839_at & DNM3 & -1.0 & Normal & 43.2 & $\mathrm{P}$ \\
& & & Tumor & 10.9 & $\mathrm{P}$ \\
\hline
\end{tabular}

Abbreviations: DNM3, dynamin 3; HCC, hepatocellular carcinoma; p, positive; ID, identification.

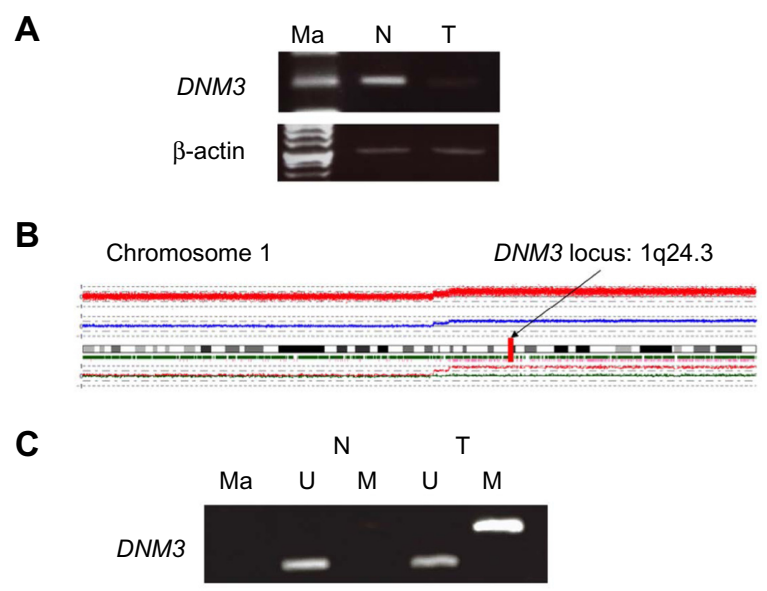

Figure I Analysis of specimens from a 68-year-old female with HCC.

Notes: (A) Semi-quantitative reverse transcription-polymerase chain reaction (RT$\mathrm{PCR}$ ) revealed down-regulation of DNM3 in tumor compared with corresponding normal tissue. (B) Copy number analysis of chromosome I using single nucleotide polymorphism arrays in HCC specimens revealed amplification of I q24.3, containing the DNM3 locus, but no deletions. (C) Methylation specific PCR revealed DNM3 promoter hypermethylation in tumor samples only.

Abbreviations: DNM3, dynamin 3; HCC, hepatocellular carcinoma; M, methylated; Ma, marker; N, normal; PCR, polymerase chain reaction; U, unmethylated; T, tumor.

We subsequently performed methylation array analysis using DNA from the same 68-year-old female HCC patient. The continuous $\beta$-values were 0.879 for tumor tissue versus 0.213 for normal tissue, indicating high methylation in the HCC sample (Table 3). Using MSP, we confirmed hypermethylation of the DNM3 promoter in tumor tissue obtained from the same HCC patient (Figure 1C). The DNM3 gene was particularly notable, since expression in cancer tissue was decreased despite amplification of the copy number of chromosome 1 containing this gene. Taken together, these results suggest that decreased expression of DNM3 in the absence of loss of heterozygosity ( $\mathrm{LOH}$ ) may be due to promoter hypermethylation.

\section{Effect of inhibiting methylation on DNM3 expression in HCC cell lines}

To confirm that silencing of DNM3 expression was due to promoter hypermethylation, we analyzed DNM3 mRNA expression in nine HCC cell lines before and after treatment with 5-aza-dC. Expression of DNM3 was clearly reactivated following 5-aza-dC treatment in three cell lines, Hep3B, HLE, and $\mathrm{HuH} 2$, as shown by semi-quantitative RT-PCR (Figure 2A).

\section{MSP and UNMSP of HCC cell lines and one primary HCC specimen}

We next investigated the methylation status of DNM3 in nine HCC cell lines using primers for (MSP) and (UNMSP). 
Table 2 Results of SNP signals at the DNM3 gene locus

\begin{tabular}{llllllc}
\hline Probe Set ID & Chromosome & Physical position & Normal call & Confidence & Tumor call & Confidence \\
\hline SNP A-4301010 & $\mathrm{I}$ & 171831910 & $\mathrm{AB}$ & 0.056641 & $\mathrm{AB}$ & $0.00830 \mathrm{I}$ \\
SNP A-2062980 & $\mathrm{I}$ & 171880994 & $\mathrm{AB}$ & 0.007813 & $\mathrm{AB}$ & 0.039063 \\
SNP A-4198760 & $\mathrm{I}$ & 172062792 & $\mathrm{AB}$ & 0.007813 & $\mathrm{AB}$ & 0.007813 \\
\hline
\end{tabular}

Abbreviations: DNM3, dynamin 3; SNP, single nucleotide polymorphism; ID, identification.

For MSP, bands of the appropriate size were observed for HepG2, Hep3B, HLE, HLF, HuH1, HuH2, HuH7, and SKHep1 cell lines (Figure 2B). For UNMSP, appropriate bands were identified in all cell lines, except $\mathrm{HuH} 2$ (Figure 2B). These results indicate complete methylation of DNM3 in $\mathrm{HuH} 2$, partial methylation in HepG2, Hep3B, HLE, HLF, $\mathrm{HuH} 1, \mathrm{HuH} 7$, and SK-Hep1 and no methylation in PLC/ $\mathrm{PRF} / 5$ cells.

\section{Sequence analysis}

To confirm the results obtained by MSP, we next performed sequence analysis of the DNM3 promoter region in $\mathrm{HuH} 2$ and PLC/PRF/5 cells. Almost all $\mathrm{CpG}$ dinucleotides in $\mathrm{HuH} 2$ were methylated, while those of $\mathrm{PLC} / \mathrm{PRF} / 5$ were unmethylated (Figure 3), thus confirming the accuracy of MSP and UNMSP.

\section{MSP and UNMSP of normal and tumor tissues from HCC patients}

We next assessed DNM3 promoter hypermethylation in tumor and normal tissues from $48 \mathrm{HCC}$ patients. Overall, $68.7 \%(33 / 48)$ of tumor samples displayed $D N M 3$ promoter hypermethylation, compared to $27 \%$ (13/48) of normal samples (Figure 4A). Thus, hypermethylation of $D N M 3$ was significantly more frequent in tumor tissues $(P<0.001)$. Four representative cases of MSP and UNMSP status are shown in Figure 4B.

\section{Analysis of DNM3 expression in normal and tumor tissues from HCC patients}

We next examined the expression of DNM3 mRNA in the 48 HCC patients by real-time quantitative RT-PCR. The DNM3 expression index was calculated as the value of the tumor tissue expression level divided by the expression level of adjacent normal tissue. Analysis of the association between methylation status and the expression index revealed that hypermethylated cancerous tissues tended to have a lower $D N M 3$ expression index than other tissues examined, however this was not statistically significant $(P=0.189$; Figure 5).

\section{Correlation between DNM3 gene expression and clinicopathological characteristics in $\mathrm{HCC}$ patients}

We next analyzed the correlation between $D N M 3$ expression and clinicopathological features of the $48 \mathrm{HCC}$ patients. Growth status (expansive growth or infiltrative growth) was the only variable associated with DNM3 expression (Table 4). We also observed that patients with decreased $D N M 3$ expression had a worse prognosis compared to patients with increased $D N M 3$ expression $(P=0.014$; Figure 6). Univariate analysis identified liver damage, cirrhosis and decreased expression of DNM3 as prognostic factors of disease specific survival, however these were not significant in multivariate analysis (Table 5).

\section{Discussion}

DNA methylation in the promoter region of several genes in HCC has been previously investigated. ${ }^{22-25}$ To detect new cancer-related genes in HCC, we developed a double combination array analysis, ${ }^{9-14}$ and triple combination array analysis including gene expression, SNP and methylation array analysis. ${ }^{15,16}$ In the current study, we used this triple combination array analysis to identify $D N M 3$ as a candidate tumor suppressor gene in HCC.

Table 3 Methylation array analysis of surgical samples from a 68-year-old female patient with HCC

\begin{tabular}{|c|c|c|c|c|c|c|c|c|}
\hline \multirow[t]{2}{*}{ Probe ID } & \multirow{2}{*}{$\begin{array}{l}\text { Gene } \\
\text { symbol }\end{array}$} & \multirow[t]{2}{*}{ Sample } & \multirow{2}{*}{$\begin{array}{l}\text { Methylation } \\
\text { value }(0-I)\end{array}$} & \multicolumn{3}{|c|}{ Status } & \multirow[t]{2}{*}{ Confidence } & \multirow{2}{*}{$\begin{array}{l}\text { Chromosomal } \\
\text { location }\end{array}$} \\
\hline & & & & Total & Unmethylated & Methylated & & \\
\hline \multirow[t]{2}{*}{ cg 23391785} & DNM3 & Normal & 0.213 & 2315 & 1799 & 516 & $3.68 \mathrm{E}-38$ & Chrlq24.3 \\
\hline & & Tumor & 0.879 & 5019 & 519 & 4500 & $3.68 \mathrm{E}-38$ & \\
\hline
\end{tabular}

Abbreviations: DNM3, dynamin 3; HCC, hepatocellular carcinoma; ID, identification. 

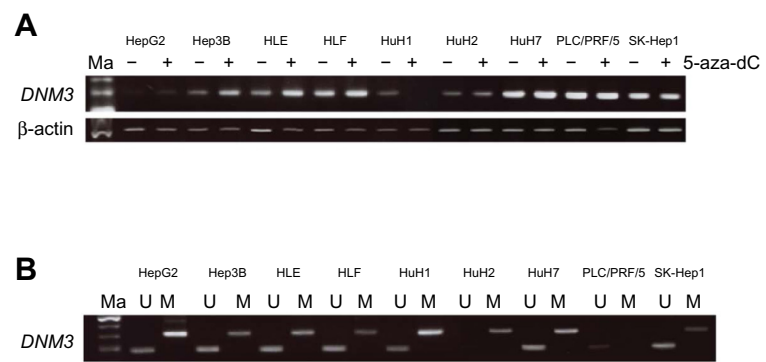

Figure 2 (A) Semi-quantitative RT-PCR revealed reactivation of DNM3 expression in three (Hep3B, HLE, and $\mathrm{HuH} 2$ ) of nine HCC cell lines. (B) MSP revealed complete methylation of DNM3 in $\mathrm{HuH}_{2}$, partial methylation in HepG2, Hep3B, HLE, HLF, $\mathrm{HuHI}, \mathrm{HuH7}$, and SK-Hepl and no methylation in PLC/PRF/5 cells.

Abbreviations: HCC, hepatocellular carcinoma; DNM3, dynamin 3; Ma, marker; 5-aza-dC, 5-aza-2'-deoxycytidine; M, methylated; U, unmethylated; MSP, methylation specific PCR. PCR, polymerase chain reaction; RT-PCR, reverse transcriptionpolymerase chain reaction.
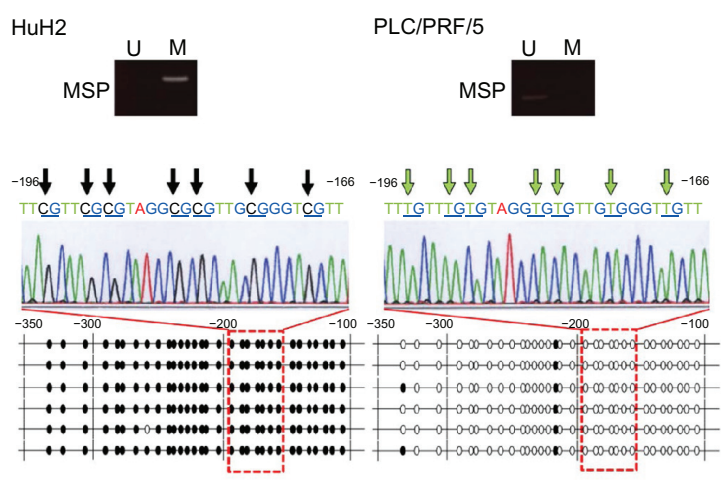

Figure 3 Sequence analysis of bisulfite-treated DNA in the DNM3 promoter region. Notes: The methylation status of $31 \mathrm{CPG}$ islands in six clones between -350 and -100 from the transcription initiation site of DNM3 exon I is shown. Closed circles represent methylated $C_{p G}$ islands; open circles indicate unmethylated $\mathrm{C}_{p G}$ islands. The $\mathrm{C}_{p} \mathrm{G}$ islands in the $\mathrm{DNM} 3$ promoter region in $\mathrm{HuH} 2$ cells were abundantly methylated, whereas $\mathrm{CpG}$ islands in $\mathrm{PLC} / \mathrm{PRF} / 5$ cells were predominantly unmethylated. Sequence analysis of CpG islands between -196 and -166 (boxed regions) is shown, where $C$ (black arrows) indicates methylated CPG islands. Bisulfite treatment converts cytosine residues to Ts (green arrows), and indicate unmethylated $C_{p}$ islands. These results validated the accuracy of MSP and UNMSP in upper region in this figure.

Abbreviations: DNA, deoxyribonucleic acid; DNM3, dynamin 3; Ma, marker; 5-azadC, 5-aza-2'-deoxycytidine; M, methylated; $U$, unmethylated; MSP, methylation specific PCR; UNMSP, Unmethylated-Specific PCR; PCR, polymerase chain reaction.

\section{A}

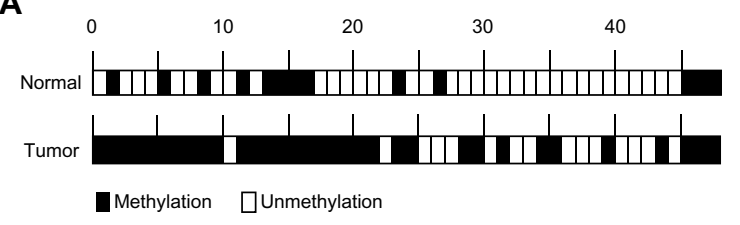

B

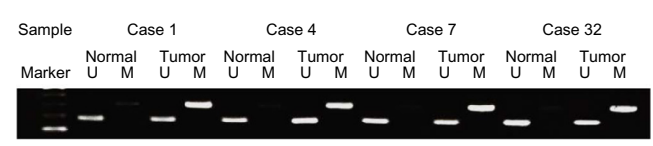

Figure 4 (A) Methylation status of DNM3 in 48 primary HCC samples. Thirty-three of $48(68.7 \%)$ cancer tissues exhibited hypermethylation of DNM3, compared to 13 of 48 (27.0\%) cases in adjacent, normal tissues. (B) Four representative cases showing hypermethylation of the promoter region of DNM3 in tumor tissues and no methylation in normal tissues.

Abbreviations: HCC, hepatocellular carcinoma; M, methylated; $U$, unmethylated; DNM3, dynamin 3.

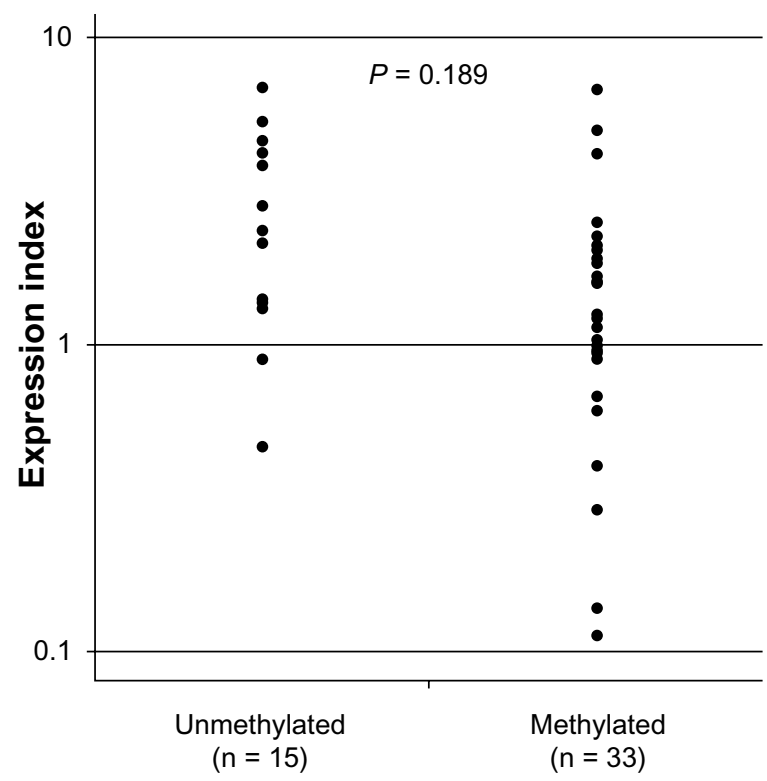

Figure 5 Expression levels of DNM3 mRNA in specimens from 48 patients with HCC. The expression index [(DNM3-tumor) $\times($ GAPDH-normal)/(DNM3normal) $\times($ GAPDH-tumor $)]$ was calculated for all 48 cases. A trend towards a lower expression index in methylated cases compared to unmethylated cases was observed, however this was not statistically significant $(P=0.189)$.

Abbreviation: HCC, hepatocellular carcinoma; DNM3, dynamin 3; GAPDH, glyceraldehyde 3-phosphate dehydrogenase.

$D N M 3$ is a member of the dynamin family of genes that are essential for endocytosis, and possess mechanochemical properties utilized to tabulate and sever membranes. ${ }^{17,26}$ To date, few studies have investigated the impact of dysregulated DNM3 expression in malignant disease. ${ }^{18,19}$ Indeed, no studies have yet been conducted to investigate the relationship between HCC and DNM3 expression. A study by Shen et al, reporting genome-wide DNA methylation profiles in $62 \mathrm{HCC}$ patients, ${ }^{27}$ identified $D N M 3$ in a subset of genes methylated in tumor tissues compared to adjacent normal tissue. However, this study did not evaluate the expression levels of DNM3 or its impact on prognostic outcome. Our current study revealed that methylation of DNM3 downregulates gene expression and is correlated with worse prognosis, suggesting that this gene may represent a novel tumor suppressor gene of HCC.

$D N M 2$ is also a member of the dynamin family. Lee et al reported that low $D N M 2$ expression was associated with tumor invasion and metastasis in invasive squamous cell carcinoma of the cervix. ${ }^{28}$ This group also demonstrated that inhibition of DNM2 enhanced the expression of metalloproteinase-2 $(M M P 2)$, a type IV collagenase, ${ }^{29}$ whose elevated expression is associated with various carcinomas, including HCC. ${ }^{30-32}$ $M M P 2$ encodes an enzyme which degrades type IV collagen, the major structured component of the basement membrane. Overexpression of $M M P 2$ may allow cancer cells to cross the epithelial basement membrane, invade surrounding stroma, 
Table 4 Correlation between DNM3 expression and clinicopathological characteristics in $48 \mathrm{HCC}$ patients

\begin{tabular}{|c|c|c|c|}
\hline Variables & $\begin{array}{l}\text { Expression } \uparrow \\
(n=14)\end{array}$ & $\begin{array}{l}\text { Expression } \downarrow \\
(n=34)\end{array}$ & $P$-value \\
\hline Age & & & $0.4 \mathrm{II}$ \\
\hline$\geq 65$ years & 8 & 15 & \\
\hline$<65$ years & 6 & 19 & \\
\hline Sex & & & 0.583 \\
\hline Male & 12 & 31 & \\
\hline Female & 2 & 3 & \\
\hline Liver damage & & & 0.112 \\
\hline$A$ & 6 & 23 & \\
\hline B & 8 & 11 & \\
\hline Cirrhosis & & & 0.411 \\
\hline Present & 8 & 15 & \\
\hline Absent & 6 & 19 & \\
\hline Virus & & & 0.986 \\
\hline $\mathrm{HBV}$ & 2 & 5 & \\
\hline $\mathrm{HCV}$ & 11 & 27 & \\
\hline Negative & I & 2 & \\
\hline Tumor & & & 0.882 \\
\hline$\geq 50 \mathrm{~mm}$ & 4 & 9 & \\
\hline$<50 \mathrm{~mm}$ & 10 & 25 & \\
\hline Tumor number & & & 0.411 \\
\hline Solitary & 7 & 24 & \\
\hline Multiple & 7 & 10 & \\
\hline $\mathrm{Fc}$ & & & 0.939 \\
\hline Present & 12 & 28 & \\
\hline Absent & 2 & 5 & \\
\hline Fc-inf & & & 0.820 \\
\hline Present & 11 & 27 & \\
\hline Absent & 2 & 6 & \\
\hline Eg or lg & & & 0.010 \\
\hline $\mathrm{Eg}$ & 9 & 32 & \\
\hline $\lg$ & 4 & I & \\
\hline Vessel invasion & & & 0.115 \\
\hline Present & 5 & 5 & \\
\hline Absent & 9 & 29 & \\
\hline AFP & & & 0.075 \\
\hline$\geq 20$ & 11 & 17 & \\
\hline$<20$ & 3 & 16 & \\
\hline Japan-Stage & & & 0.121 \\
\hline$I+I I$ & 7 & 25 & \\
\hline $\mathrm{III}+\mathrm{IVa}$ & 7 & 9 & \\
\hline
\end{tabular}

Abbreviations: AFP, alpha-fetoprotein; DNM3, dynamin 3; Eg, expansive growth; $\mathrm{Fc}$, formation of capsule; Fc-inf, infiltration to capsule; HBV, hepatitis B virus; $\mathrm{HCC}$, hepatocellular carcinoma; $\mathrm{HCV}$, hepatitis $\mathrm{C}$ virus; lg, infiltrative growth.

Table 5 Prognostic factors for disease specific survival for $48 \mathrm{HCC}$ patients in univariate and multivariate analysis

\begin{tabular}{|c|c|c|c|c|c|c|}
\hline & \multicolumn{3}{|c|}{ Univariate analysis } & \multicolumn{3}{|c|}{ Multivariate analysis } \\
\hline & HR & $95 \% \mathrm{Cl}$ & $P$-value & HR & $95 \% \mathrm{Cl}$ & $P$-value \\
\hline $\begin{array}{l}\text { Liver } \\
\text { damage }\end{array}$ & 2.61 & $1.22-5.58$ & 0.014 & 1.98 & $0.85-4.26$ & 0.114 \\
\hline Cirrhosis & 2.30 & $1.09-4.9 \mid$ & 0.027 & 2.00 & $0.93-4.38$ & 0.075 \\
\hline $\begin{array}{l}\text { DNM3 } \\
\text { expression }\end{array}$ & 2.50 & $1.15-5.30$ & 0.021 & 2.09 & $0.93-4.58$ & 0.070 \\
\hline
\end{tabular}

Abbreviations: $\mathrm{Cl}$, confidence interval; DNM3, dynamin 3; HCC, hepatocellular carcinoma; HR, hazard ratio.

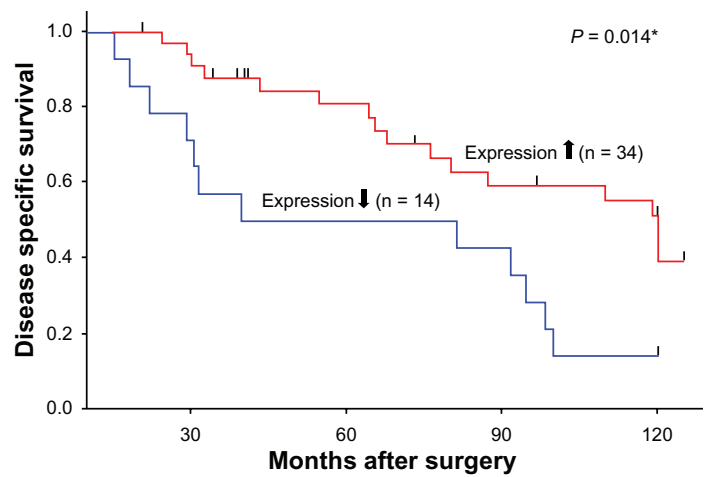

Figure 6 Disease specific survival stratified by DNM3 (dynamin 3) expression status. Patients with lower DNM3 expression exhibited poorer prognosis with decreased disease specific survival, compared to patients with higher DNM3 expression $(P=0.014)$. Note: *, statistically significant.

enter blood vessels or lymphatics, extravasate and establish new proliferating colonies. ${ }^{31}$ Therefore, decreased expression of DNM3 by promoter methylation may increase the expression of $M M P 2$, thereby contributing to the poor prognosis of these patients.

Using our triple array analysis, we have extracted an interesting molecule, DNM3, and verified an association between gene expression and carcinogenesis or tumor progression, using a panel of 48 primary human specimens. It may be pointed out that the efficiency of the extraction of interesting molecules will be increased if we use multiple cases for arrays. Although we had to check data from many genes for extracting the molecule from array data of one HCC patient, it seems that the results of triple combination array analysis were reliable because we have reported our results after investigation of as many as 48 samples of HCC cases.

In clinical practice, $D N M 3$ expression may be used as a prognostic biomarker for resected HCC patients. The methylation of certain genes, for example $p 15$ in myelodysplastic syndrome (MDS) patients is well documented, ${ }^{33}$ and hypomethylating agents such as 5-aza-2'-deoxycytidine (decitabine) have already been introduced in the clinical setting for MDS patients. ${ }^{34}$ In the future, decitabine may also be used in patients with aberrant methylation of DNM3.

In conclusion, we identify $D N M 3$ as a new candidate tumor suppressor gene in HCC by triple combination array analysis. Further studies are required to confirm the role of this gene as a tumor suppressor in carcinogenesis.

\section{Acknowledgments}

This work was supported by Japan Society for the Promotion of Science (JSPS) KAKENHI Grant-in-Aid for Scientific Research (C) Number 22591427. 


\section{Disclosure}

The authors report no conflicts of interest in this work.

\section{References}

1. Ferlay J, Shin HR, Bray F, Forman D, Mathers C, Parkin DM. Estimates of worldwide burden of cancer in 2008: GLOBOCAN 2008. Int J Cancer. 2010;127(12):2893-2917.

2. Forner A, Llovet JM, Bruix J. Hepatocellular carcinoma. Lancet. 2012;379(9822):1245-1255.

3. Livraghi T, Goldberg SN, Lazzaroni S, Meloni F, Solbiati L, Gazelle GS. Small hepatocellular carcinoma: treatment with radio-frequency ablation versus ethanol injection. Radiology. 1999;210(3):655-661.

4. Takayasu K, Arii S, Ikai I, et al; Liver Cancer Study Group of Japan. Prospective cohort study of transarterial chemoembolization for unresectable hepatocellular carcinoma in 8510 patients. Gastroenterology. 2006;131(2):461-469.

5. Llovet JM, Ricci S, Mazzaferro V, et al; SHARP Investigators Study Group. Sorafenib in advanced hepatocellular carcinoma. N Engl J Med. 2008;359(4):378-390.

6. Yu MC, Yuan JM. Environmental factors and risk for hepatocellular carcinoma. Gastroenterology. 2004;127(5 Suppl 1):S72-S78.

7. Cusnir M, Patt YZ. Novel systemic therapy options for hepatocellular carcinoma. Cancer J. 2004;10(2):97-103.

8. El-Serag HB, Rudolph KL. Hepatocellular carcinoma: epidemiology and molecular carcinogenesis. Gastroenterology. 2007;132(7): $2557-2576$.

9. Kanda M, Nomoto S, Okamura Y, et al. Detection of metallothionein $1 \mathrm{G}$ as a methylated tumor suppressor gene in human hepatocellular carcinoma using a novel method of double combination array analysis. Int J Oncol. 2009;35(3):477-483.

10. Nomoto S, Kanda M, Okamura Y, et al. Epidermal growth factorcontaining fibulin-like extracellular matrix protein 1, EFEMP1, a novel tumor-suppressor gene detected in hepatocellular carcinoma using double combination array analysis. Ann Surg Oncol. 2010;17(3): 923-932.

11. Okamura Y, Nomoto S, Kanda M, et al. Leukemia inhibitory factor receptor (LIFR) is detected as a novel suppressor gene of hepatocellular carcinoma using double-combination array. Cancer Lett. 2010;289(2): 170-177.

12. Okamura $Y$, Nomoto $S$, Kanda $M$, et al. Reduced expression of reelin (RELN) gene is associated with high recurrence rate of hepatocellular carcinoma. Ann Surg Oncol. 2011;18(2):572-579.

13. Kanda M, Nomoto S, Okamura Y, et al. Promoter hypermethylation of fibulin 1 gene is associated with tumor progression in hepatocellular carcinoma. Mol Carcinog. 2011;50(8):571-579.

14. Hayashi M, Nomoto S, Kanda M, et al. Identification of the A kinase anchor protein 12 (AKAP12) gene as a candidate tumor suppressor of hepatocellular carcinoma. J Surg Oncol. 2012;105(4):381-386.

15. Okamura Y, Nomoto S, Hayashi M, et al. Identification of the bleomycin hydrolase gene as a methylated tumor suppressor gene in hepatocellular carcinoma using a novel triple-combination array method. Cancer Lett. 2011;312(2):150-157.

OncoTargets and Therapy

\section{Publish your work in this journal}

OncoTargets and Therapy is an international, peer-reviewed, open access journal focusing on the pathological basis of all cancers, potential targets for therapy and treatment protocols employed to improve the management of cancer patients. The journal also focuses on the impact of management programs and new therapeutic agents and protocols on

Submit your manuscript here: http://www.dovepress.com/oncotargets-and-therapy-journal
16. Hishida M, Nomoto S, Inokawa $\mathrm{Y}$, et al. Estrogen receptor 1 gene as a tumor suppressor gene in hepatocellular carcinoma detected by triplecombination array analysis. Int $J$ Oncol. 2013;43(1):88-94.

17. Orth JD, McNiven MA. Dynamin at the actin-membrane interface. Curr Opin Cell Biol. 2003;15(1):31-39.

18. Booken N, Gratchev A, Utikal J, et al. Sézary syndrome is a unique cutaneous T-cell lymphoma as identified by an expanded gene signature including diagnostic marker molecules CDO1 and DNM3. Leukemia. 2008;22(2):393-399.

19. Teicher BA. Searching for molecular targets in sarcoma. Biochem Pharmacol. 2012;84(1):1-10.

20. Bibikova M, Fan JB. GoldenGate assay for DNA methylation profiling. Methods Mol Biol. 2009;507:149-163.

21. Takai D, Jones PA. The CpG island searcher: a new WWW resource. In Silico Biol (Gedrukt). 2003;3(3):235-240.

22. Yoshikawa H, Matsubara K, Qian GS, et al. SOCS-1, a negative regulator of the JAK/STAT pathway, is silenced by methylation in human hepatocellular carcinoma and shows growth-suppression activity. Nat Genet. 2001;28(1):29-35.

23. Wong IH, Lo YM, Zhang J, et al. Detection of aberrant p16 methylation in the plasma and serum of liver cancer patients. Cancer Res. 1999; 59(1):71-73.

24. Yang B, Guo M, Herman JG, Clark DP. Aberrant promoter methylation profiles of tumor suppressor genes in hepatocellular carcinoma. Am J Pathol. 2003;163(3):1101-1107.

25. Lee S, Lee HJ, Kim JH, Lee HS, Jang JJ, Kang GH. Aberrant CpG island hypermethylation along multistep hepatocarcinogenesis. Am J Pathol. 2003;163(4):1371-1378.

26. Sever S. Dynamin and endocytosis. Curr Opin Cell Biol. 2002;14(4): 463-467.

27. Shen J, Wang S, Zhang YJ, et al. Genome-wide DNA methylation profiles in hepatocellular carcinoma. Hepatology. 2012;55(6):1799-1808.

28. Lee YY, Do IG, Park YA, et al. Low dynamin 2 expression is associated with tumor invasion and metastasis in invasive squamous cell carcinoma of cervix. Cancer Biol Ther. 2010;10(4):329-335.

29. Devarajan P, Johnston JJ, Ginsberg SS, Van Wart HE, Berliner N. Structure and expression of neutrophil gelatinase cDNA. Identity with type IV collagenase from HT1080 cells. J Biol Chem. 1992;267(35):25228-25232.

30. Gao J, Ding F, Liu Q, Yao Y. Knockdown of MACC1 expression suppressed hepatocellular carcinoma cell migration and invasion and inhibited expression of MMP2 and MMP9. Mol Cell Biochem. 2013;376(1-2):21-32.

31. Egeblad M, Werb Z. New functions for the matrix metalloproteinases in cancer progression. Nat Rev Cancer. 2002;2(3):161-174.

32. Deryugina EI, Quigley JP. Matrix metalloproteinases and tumor metastasis. Cancer Metastasis Rev. 2006;25(1):9-34.

33. Daskalakis M, Nguyen TT, Nguyen C, et al. Demethylation of a hypermethylated P15/INK4B gene in patients with myelodysplastic syndrome by 5 -Aza-2'-deoxycytidine (decitabine) treatment. Blood. 2002;100(8):2957-2964.

34. Kantarjian H, Issa JP, Rosenfeld CS, et al. Decitabine improves patient outcomes in myelodysplastic syndromes: results of a phase III randomized study. Cancer. 2006;106(8):1794-1803. patient perspectives such as quality of life, adherence and satisfaction The manuscript management system is completely online and includes a very quick and fair peer-review system, which is all easy to use. Visit $\mathrm{http}: / /$ www.dovepress.com/testimonials.php to read real quotes from published authors. 